\title{
Experimentation and Stages of Acquisition for Tobacco Consumption in Spanish Adolescents
}

\author{
Sílvia Font-Mayolas ${ }^{1, *}$, M. Eugènia Gras ${ }^{1}$, Montserrat Planes ${ }^{1}$ and Mark J.M. Sullman ${ }^{2}$ \\ ${ }^{1}$ Quality of Life Research Institute, University of Girona, Catalonia, Spain \\ ${ }^{2}$ School of Psychology, University of Hertfordshire, Hatfield, Herts, AL10 9AB, 10UK
}

\begin{abstract}
One area which has been largely neglected when studying the acquisition of addiction to smoking with the transtheoretical model is whether the individual had previously experimented with smoking. The importance of including the experimentation variable was supported by this research.
\end{abstract}

Keywords: Stages of change, prevention, smoking acquisition, Spanish adolescents.

\section{INTRODUCTION}

The process of becoming a smoker during adolescence has been conceptualised by many researchers as the progression through a sequence of stages of development [1-3]. The Transtheoretical Model of Change (TMC) [4] has been extensively used to explain the cessation of smoking, although several authors have contested its validity [5-7]. Moreover the TMC has been adapted to the acquisition of smoking by Stern, Prochaska, Velicer \& Elder [8]. These authors differentiate between four stages in the acquisition process: precontemplation (the adolescents have not begun to think about smoking or have no desire to start smoking in the future); contemplation (these youngsters are thinking about starting to smoke); action (these individuals have begun to experiment with cigarettes and are deciding whether or not it is for them); and maintenance (these adolescents are smoking on a more regular basis and are committed to smoking now and in the future).

Although the topic of stages of change for smoking cessation has received much evaluation and criticism, the topic of stages of smoking acquisition, in relation too experimentation, has received little attention. Adolescents who have never experimented with smoking do not have the same risk of becoming smokers as those who have tried it [9]. The TMC, as adapted by Stern et al. [8], takes this variable into account. Surprisingly, however, more recent studies using the TMC have not always differentiated between those who have and those who have not experimented (Table 1).

For example, a previous study [10] used the TMC to study the acquisition of smoking in a sample of American adolescents. In the acquisition stages, these authors included non-smokers who stated they had never smoked regularly (weekly or more often), whether they had ever experimented with smoking or not. In addition, when classifying a sample of adolescents from six European countries (Finland,

*Address correspondence to this author at the Quality of Life Research Institute, University of Girona, Emili Grahit Street, 77, 17071 Girona Catalonia, Spain; Tel: +34 972-41-83-53; Fax: +34 972-41-83-01;

E-mail: silvia.font@udg.edu
Denmark, the United Kingdom, the Netherlands, Spain and Portugal) previous research [9] distinguished between three subtypes in the precontemplation stage and considered nonsmokers to include adolescents who had experimented with smoking. Furthermore, in another piece of research on American adolescents the authors [11] asked about the acquisition stage of tobacco consumption and of experimenting (I have never tried a cigarette, I have tried them but not on a weekly basis, I tried them but I gave up, and I currently smoke). However, strangely they did not report whether the first three categories of experimenting corresponded to participants classified in the acquisition stages. In another American study the authors [12] considered non-smokers to be adolescents who said they had never smoked and those who had tried smoking a couple of times (but who do not smoke now), without distinguishing between these groups when sorting them into stages.

The objectives of this study were:

1. To compare the distribution of a sample of Spanish adolescents in the acquisition stages of smoking with previous studies carried out on American and European samples.

2. To study the role of experimenting with smoking, or the intention of becoming a consumer in the near future.

This information is important in order to help developing guidelines for tailoring interventions and also to investigate the utility of incorporating the experimentation variable into the TMC.

\section{METHODS}

\section{Subjects}

Spain has compulsory schooling until 16 years old. The participants were 1,510 Secondary School students (50.9\% female) aged between 12 and 17 years (mean age $=14.2$; SD $=1.3$ ) from all public schools in the city of Girona (Spain). After taking permission from the person in charge of each school, the questionnaires were administered to the students 
Table 1. Review of the Various Studies on the Acquisition Stages of Tobacco Consumption in Adolescents, According to the Use of the Experimentation Variable

\begin{tabular}{|c|c|c|c|}
\hline Study & Definition* and Classification by Stages & & Experimentation \\
\hline $\begin{array}{l}\text { Pallonen et al. } \\
\begin{array}{l}(1998) \\
\mathrm{n}=490\end{array} \\
\text { Age range }=15-17 \\
\text { years }\end{array}$ & $\begin{array}{l}\text { Precontemplation } \\
\text { (not thinking about trying smoking in the next } 6 \text { months) } \\
\text { Contemplation } \\
\text { (thinking about trying smoking in the next } 6 \text { months) } \\
\text { Preparation } \\
\text { (thinking about starting smoking in the next } 30 \text { days) }\end{array}$ & $\begin{array}{l}93.2 \% \\
3.1 \% \\
3.7 \%\end{array}$ & Never having smoked, or not regularly (weekly or more). \\
\hline $\begin{array}{l}\text { Kremers et al. } \\
(2001) \\
\mathrm{n}=21535 \\
\text { Mean age }=13.3 \\
\text { years }\end{array}$ & $\begin{array}{l}\text { Precontemplation } \\
\text { a) Progressives } \\
\text { (intending to start smoking within the next } 5 \text { years) } \\
\text { b) Immotives } \\
\text { ( not intending to start within the next } 5 \text { years but } \\
\text { lacking a strong decision never to start smoking) } \\
\text { c) Committers } \\
\text { (sure to never start smoking and not intending } \\
\text { to smoke in the next year or in the future) } \\
\text { Contemplation } \\
\text { Preparation }\end{array}$ & $\begin{array}{l}36.3 \% \\
0.1 \% \\
2.5 \%\end{array}$ & $\begin{array}{l}\text { Never having smoked }(68.13 \%) \text { or having tried tobacco } \\
\text { or having experienced consumption, but not weekly } \\
(31.87 \%)\end{array}$ \\
\hline $\begin{array}{l}\text { Plummer et al. } \\
(2001) \\
\mathrm{n}=2010 \\
\text { Mean age = } 15.2 \\
\text { years }\end{array}$ & $\begin{array}{l}\text { Precontemplation } \\
\text { Contemplation } \\
\text { Preparation }\end{array}$ & $\begin{array}{c}87.4 \% \\
7.7 \% \\
4.9 \%\end{array}$ & $\begin{array}{l}\text { They were asked about experimenting but did not state } \\
\text { who they considered to be non-smokers. }\end{array}$ \\
\hline
\end{tabular}

* The stage is defined only on the first occasion, following stages of the same name have the same definition.

during normal class time. All students present in the classroom on the date of the survey agreed to answer the questionnaire. Participants were assured of the anonymity and confidentiality of their responses.

\section{Stages of Change}

Participants were categorised into the stages of change using the standard definitions [10]. Students who reported that they were not thinking about trying smoking in the next 6 months were placed into the precontemplation group. Adolescents thinking about trying smoking in the next 6 months were placed into the contemplation group. Participants who reported that they were thinking about starting in the next 30 days were considered to be in the preparation stage. Students who had been smoking cigarettes regularly (or occasionally) for less than 6 months were classified in the recent action stage and those who had been smoking regularly for 6 months or more were placed in a stage called action.

\section{Experimentation with the Substance}

Participants were place into two groups: those who reported that they had never tried tobacco and those who reported that they had tried it.

\section{RESULTS}

Table 2 shows the distribution of adolescents according to the stage of addiction acquisition to tobacco, by gender and age. $18.7 \%$ of the participants were smokers (in the recent and action stages) and another 5.8\% intended to smoke in the near or not so near future (contemplation and preparation). There were no significant differences between males and females across the different stages $\left(\mathrm{X}_{(4)}^{2}=9.2 ; \mathrm{p}=.06\right)$. In contrast, age appears to be a relevant variable for predicting the acquisition stage: as age increases proportionally more adolescents are at a higher stage of addiction to tobacco $\left(\mathrm{X}_{(8)}^{2}=128.1 ; \mathrm{p}<.0005\right)$. 
Table 2. Percentage of Adolescents According to the Acquisition Stage of Addiction to Tobacco (Pallonen et al., 1998), by Gender and Age

\begin{tabular}{|c|c|c|c|}
\hline Acquisition Stage & $\begin{array}{c}\text { Males } \\
\mathrm{n}=741\end{array}$ & $\begin{array}{c}\text { Females } \\
n=769\end{array}$ & $\begin{array}{c}\text { Total Sample } \\
n=1510\end{array}$ \\
\hline Precontemplation & 77.5 & 73.5 & 75.4 \\
\hline Contemplation & 4.0 & 4.2 & 4.1 \\
\hline Preparation & 2.2 & 1.3 & 1.7 \\
\hline Recent Action & 9.0 & 9.8 & 9.4 \\
\hline Action & 7.3 & 11.3 & 9.3 \\
\hline \multirow{2}{*}{ Acquisition Stage } & \multicolumn{3}{|c|}{ Age } \\
\hline & $\begin{array}{c}12-13 \\
n=471\end{array}$ & $\begin{array}{c}14-15 \\
n=797\end{array}$ & $\begin{array}{c}16 \text { or more } \\
n=242\end{array}$ \\
\hline Precontemplation & 91.7 & 69.8 & 62.0 \\
\hline Contemplation & 1.3 & 4.9 & 7.0 \\
\hline Preparation & 1.5 & 2.4 & - \\
\hline Recent Action & 4.0 & 11.9 & 11.6 \\
\hline Action & 1.5 & 11.0 & 19.4 \\
\hline
\end{tabular}

The distribution of non-smoking adolescents according to the acquisition stage of addiction, and their previous experience with tobacco, by gender and age is presented in Table $\mathbf{3}$. In the group of adolescents who had at some time tried the substance, the percentages in the contemplation and preparation stages (13.2\%) was appreciably higher than amongst those who had never tried smoking $(4 \%)\left(\mathrm{X}_{(2)}^{2}=35.7\right.$; $\mathrm{p}<.00005)$. The same pattern was also found when males $\left(\mathrm{X}^{2}{ }_{(2)}=14.7 ; \mathrm{p}=.001\right)$ and females $\left(\mathrm{X}^{2}{ }_{(2)}=21.8 ; \mathrm{p}<.0005\right)$ were analysed separately. A similar pattern can also be seen for age, but only the 14-15 years old group was significantly different $\left(\mathrm{X}_{(2)}^{2}=24.5 ; \mathrm{p}<.0005\right)$.

\section{DISCUSSION}

The results of this research show that like American and European adolescents $[9,11]$ the Spanish adolescents studied are mainly in the precontemplation stage. The present study also found that more experimenters, than those who had never experimented, reported their intention to become smokers in the near future. This differential risk with regard to start smoking was independent of gender but not of age, within the 14-15 years old adolescents being the most sensible group.

These findings support the research conducted by Kremers et al. [9], who found that it was more common to find adolescents who had experimented with cigarettes, than adolescents without experience, in the progressive stage of preparation. However, when an adolescent who had never tried tobacco is asked whether he or she intends to initiate consumption in the near or not so near future, their interpretation of this question may not be the same as someone who had previously experimented his/her smoking. In the first case the "intention to consume" could be interpreted as the "intention to experiment" or to try a previously unknown substance, in this case the adolescent would be at an earlier stage of the acquisition process than the adolescent who has already experimented, stating his or her intention to become a smoker. Therefore, in order to contribute to detection of youth at high risk for substance use disorders [13, 14], there is a need to include the experimentation variable in future research using the Transtheoretical Model of Change (TMC) to study smoking amongst adolescents.

As other authors suggest $[12,15]$, in order to improve the results of prevention campaigns particular attention should be given to the subgroup of adolescents who are most at risk. One very important undertaking would be to prevent adolescents from experimenting with cigarettes in order to help and keep them in the precontemplation stage of acquisition for a longer period of time. Therefore, as other authors have proposed, the goal of a tailored intervention would be to develop unique materials appropriate for each stage to avoid the progression to the next stage of addiction $[12,16]$.

Table 3. Percentage of Non-Smoking Adolescents According to Each Stage of Addiction and their Previous Experience with Smoking, by Gender and Age

\begin{tabular}{|c|c|c|c|c|c|c|}
\hline \multirow[b]{2}{*}{ Acquisition Stage } & \multicolumn{2}{|c|}{ Never Tried } & \multicolumn{2}{|c|}{ Experimenter } & \multicolumn{2}{|c|}{ Total Non Smokers } \\
\hline & $\begin{array}{c}\text { Males } \\
\mathrm{n}=\mathbf{4 1 4}\end{array}$ & $\begin{array}{c}\text { Females } \\
\mathbf{n}=\mathbf{3 9 0}\end{array}$ & $\begin{array}{l}\text { Males } \\
\mathrm{n}=\mathbf{2 0 6}\end{array}$ & $\begin{array}{c}\text { Females } \\
\mathbf{n}=\mathbf{2 1 7}\end{array}$ & $\begin{array}{c}\text { Males } \\
\mathrm{n}=\mathbf{6 2 0}\end{array}$ & $\begin{array}{c}\text { Females } \\
\mathbf{n}=607\end{array}$ \\
\hline Precontemplation & 95.4 & 96.7 & 86.9 & 86.6 & 92.6 & 93.1 \\
\hline Contemplation & 3.1 & 2.6 & 8.3 & 10.1 & 4.8 & 5.3 \\
\hline Preparation & 1.4 & .8 & 4.9 & 3.2 & 2.6 & 1.6 \\
\hline \multirow[b]{2}{*}{ Acquisition Stage } & \multicolumn{3}{|c|}{ Never Tried } & \multicolumn{3}{|c|}{ Experimenter } \\
\hline & $\begin{array}{c}12-13 \\
n=358\end{array}$ & $\begin{array}{c}14-15 \\
n=366\end{array}$ & $\begin{array}{c}16 \text { or more } \\
n=79\end{array}$ & $\begin{array}{l}12-13 \\
n=87\end{array}$ & $\begin{array}{c}14-15 \\
n=248\end{array}$ & $\begin{array}{c}16 \text { or More } \\
n=88\end{array}$ \\
\hline Precontemplation & 97.5 & 95.4 & 92.4 & 95.4 & 83.5 & 87.5 \\
\hline Contemplation & 1.4 & 3.3 & 7.6 & 1.1 & 10.9 & 12.5 \\
\hline Preparation & 1.1 & 1.4 & - & 3.4 & 5.6 & - \\
\hline
\end{tabular}


On the other hand, the transtheoretical model of change for tobacco acquisition has a number of problems, such as spurious cut-off points between the various stages. For example, an individual who reports that he is thinking about starting smoking in the next 30 days is categorised differently from someone who reports that he will start smoking in 40 days. Furthermore, it is also possible that individuals may not pass through the stages in the manner predicted by the TMC and that these changes in stage could potentially occur within the space of a few days. Therefore, future research is needed to clarify the extent of these weaknesses [17].

There are a number of possible methodological limitations to this study. As all the participants studied were in Girona, there is a possibility that they might significantly differ from the general Spanish adolescent population. The present study also suffers from the usual perceived weakness of research using self-reported data. The most common criticism of self-reported is the possibility that it suffers from social desirability bias. However, as confidentiality and anonymity were guaranteed we would expect this effect to be minimal. In addition, the cross-sectional and nonexperimental nature of the study poses some problems regarding the interpretation of the results. Therefore, future research is needed using a longitudinal design. Future research should also be conducted elsewhere in Spain to confirm these findings.

\section{ACKNOWLEDGEMENTS}

Grant SEJ2007-60814/PSIC of Spanish Ministry of Education supported this research.

\section{REFERENCES}

[1] Kaufman NJ, Castrucci BC, Mowery PD, Gerlach KK, Emont S, Orleans T. Predictors of change on the smoking uptake continuum among adolescents. Arch Ped Adol Med 2002; 156: 581-7.

[2] Mayhew KP, Flay BR, Mott JA. Stages in the development of adolescent smoking. Drug Alc Dep 2000; 59(Supp. 1): S61-81.

[3] U.S. Department of Health and Human Services. Preventing tobacco use among young people: a report of the Surgeon General.
Department of Health and Human Services, Centers for Disease Control and Prevention, Office on Smoking and Health, Atlanta, Georgia 1994.

[4] Prochaska JO, Di Clemente CC. Stages and processes of self-change of smoking: toward an integrative model of change. J Cons Clin Psychol 1983; 51(3): 390-5.

[5] Font-Mayolas S, Planes M, Gras ME, Sullman MJM. Motivation for change and pros and cons in Spanish population. Addict Behav 2007; 32: 175-180.

[6] Herzog TA. Are the stages of change for smokers qualitatively distinct? An analysis using adolescent sample. Psychol Addict Behav 2007; 21(1): 120-5.

[7] Zullino D, Besson J, Schnyder C. Stage of change of cigarette smoking in alcohol-dependent patients. Eur Addict Res 2000; 6: 84-90.

[8] Stern RA, Prochaska JO, Velicer WF, Elder JP. Stages of adolescent cigarette smoking acquisition: measurement and sample profiles. Addict Behav 1987; 12(4): 319-29.

[9] Kremers SPJ, Mudde AN, de Vries H. Subtypes within the precontemplation stage of adolescent smoking acquisition. Addict Behav 2001; 26: 237-51.

[10] Pallonen UE, Prochaska JO, Velicer WF, Prokhorov AV, Smith NF. Stages of acquisition and cessation for adolescent smoking: an empirical integration. Addict Behav 1998; 23(3): 303-24.

[11] Plummer BA, Velicer WF, Redding CA, et al. Stage of change, decisional balance, and temptations for smoking. Measurement and validation in a large, school-based population of adolescents. Addict Behav 2001; 26: 551-71.

[12] Velicer WF, Redding CA, Anatchkova MD, Fava JL, Prochaska JO. Identifying cluster subtypes for the prevention of adolescent smoking acquisition. Addict Behav 2007; 32: 228-47.

[13] Kirisci L, Vanyukov M, Tarter R. Detection of youth at high risk for substance use disorders: a longitudinal study. Psychol Addict Behav 2005; 19(3): 243-52.

[14] Nyári TA, Herédi K, Parker L. Addictive behaviour of adolescents in seconday schools in Hungary. Eur Addict Res 2005; 11: 38-43.

[15] Kuntsche EN. Progression of a general substance use pattern among adolescents in Switzerland Investigating the relationship between alcohol, tobacco, and cannabis use over a 12-year period. Eur Addict Res 2004; 10: 118-25.

[16] Johnson JL, Evers KE, Paiva AL, et al. Prevention profiles: understanding youth who do not use substances. Addict Behav 2006; 31(9): 1593-1606.

[17] Spencer L, Pagell F, Hallion ME, Adams TB. Applying the transtheoretical model to tobaco cessation and prevention: a revision of literature. Am J Health Promot 2002; 17(1): 7-71. 